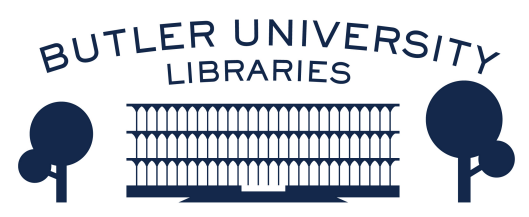

Journal of Hindu-Christian Studies

Volume 24

Article 20

November 2011

\title{
Book Review: "Comparative Theology and the Problem of Religious Rivalry"
}

Jon Paul Sydnor

Follow this and additional works at: https://digitalcommons.butler.edu/jhcs

Part of the Religion Commons

\section{Recommended Citation}

Sydnor, Jon Paul (2011) "Book Review: "Comparative Theology and the Problem of Religious Rivalry"," Journal of Hindu-Christian Studies: Vol. 24, Article 20.

Available at: https://doi.org/10.7825/2164-6279.1497

The Journal of Hindu-Christian Studies is a publication of the Society for Hindu-Christian Studies. The digital version is made available by Digital Commons @ Butler University. For questions about the Journal or the Society, please contact cbauman@butler.edu. For more information about Digital Commons @ Butler University, please contact digitalscholarship@butler.edu. 
table" (149).

Although taking the critiques seriously, Clooney gives some good responses at the end of the book. In reading his response to Kiblinger's critique one is reminded of the Buddhist parable of the arrow: What difference does it make to the practical process of extracting the arrow to know who shot it? Clooney states, "In the end, it is not clear how my own work, such as my current exploration of the presence and absence of God in the traditions of the Song [of Songs] and Tiruvaymoli, would be improved by constructing for it an explicit Christian theology of religions that might then be applied to Srivaisnava Hinduism" (196). With regard to the critique that he and other comparativists have not escaped far enough from their roots because they don't consider "outsiders within," he writes, "There is no end to the broadening, corrective process, and we need also to be concerned about race, literacy and orality, economic status, and how different religions need to be treated differently. The list of concerns can become overwhelming, and we will end up focusing on some correctives more than others" (197).

This book should be a standard component of the library of the comparativist. Through critiquing the field and through its many examples of comparison the book shows new possibilities and directions for comparative theology.

Edward T. Ulrich

University of St. Thomas

\section{Comparative Theology and the Problem of Religious Rivalry. By Hugh Nicholson. New York: Oxford University Press, 2011. 320 pages}

HUGH Nicholson believes comparative theology to be an undertheorized discipline. The lack of fundamental reflection, in his view, presents at least two problems. One, it marginalizes comparative theology within the broader theological discourse, since comparative theology cannot establish its own methodological validity (47). Second, the lack of fundamental reflection increases the likelihood that comparative theology itself will misstep as it pursues comparison without adequate epistemological or ethical reflection. Nicholson's book attempts to address these problems by providing ethical and epistemological reflection on comparative theology and the problem of religious rivalry.

For such a thoughtful and lengthy book, a review can only provide the most basic summary. In order to focus this review, I will concentrate on the constructive portions of Nicholson's groundbreaking study.

Nicholson seeks to disabuse comparative theologians of the myth that theirs is an innocent, apolitical discipline. Instead, comparative theology is, along with all theology, a political endeavor. Indeed, comparative theology as a discipline is especially fraught with politics, as it necessarily invokes the power of oppositional identity. While comparative theologians may consider themselves enlightened practitioners of interreligious discourse, failure to acknowledge the dangers inherent in such discourse risks real harm. Nicholson's book plunges to the heart of this problem by addressing the problem of oppositional identity in comparative theology (ix-x).

Nicholson diagnoses two moments in the development of an oppositional, exclusive, political identity. The first moment involves the "political" act of exclusion itself. Relying on the work of Mark Heim and Carl Schmitt, Nicholson deems this moment to be inevitable. All social, political, and theological positions are exclusive. Sure, exclusivism excludes pluralism. But just as surely, pluralism excludes exclusivism (8).

Nicholson concludes that exclusion, hence politics, extends "all the way down". He devotes Chapter Two of his book to a study of "The 
Modern Quest to Depoliticize Theology". There he presents evidence in support of Carl Schmitt's "depoliticization thesis", which argues for the inevitability of political striving between groups, hence the failure of any attempt to depoliticize human interactions. Nicholson finds within theology a similar inevitable striving between theological schools. The failure of natural religion, Schleiermacher's true church, universalism, pluralism, postliberalism, etc. to end this striving proves Schmitt's thesis. Each school simply became another place from which to strive.

Following Schmitt's analysis of culture, Nicholson applies the "inescapability of the political" to all theology (80), including comparative theology. Due to its undeveloped methodological reflection, comparative theology misunderstands itself as non-hegemonic and non-political (29). Nicholson, on the other hand, asserts that the entirety of religious discourse and practice is implicated in relations of religious rivalry (10). Comparative theology, then, merely represents the latest vain attempt of liberal theology to avoid the political/exclusive. Another approach is needed.

In response to this diagnosis, Nicholson concerns himself with the second moment in the development of identity, the moment deemed reification or naturalization. In the first moment, groups develop their identity in relation to other groups, but not necessarily in opposition to other groups. However, the contingent identity developed in relation to another group gradually becomes an essentialized identity held in opposition to another group. At this point, the cultural beliefs of the in-group are perceived as natural and good, while the cultural beliefs of the out-group are perceived as unnatural and deviant.

Nicholson believes that theology can be denaturalized but not depoliticized. In fact, he doesn't even consider the political, exclusive nature of theological positions to be problematic (81). Instead, he sees a benefit in Chantal Mouffe and William Connolly's agonistic pluralism, which advocates a relational theory of identity in which "identity is mobilized on the basis of differences that come to be recognized in the course of social interaction" (80-81).
The problem is not exclusion but the ideological stabilization of identity (84). Once an in-group deems its beliefs (here, theology) to be transhistorical and transcultural, then those out-groups that offer alternatives will be interpreted as abnormal and regarded with hostility. The in-group will need to protect itself and its thought-world from the out-group. In so doing, the in-group's thought world will become hard, static, and intolerant. Difference becomes otherized or worse, dehumanized.

Given this dynamic, the process of denaturalization will promote respect and dynamism. According to Nicholson, one of the most powerful methods of undercutting the ideological stabilization of identity is comparison. "Cross-cultural comparisons deconstruct the metonymic, simplified, binary oppositions created during exclusion" (16). Comparison reveals held truths to be historical, constructed, and contingent, and comparison treats the other as an opportunity rather than a threat.

Nicholson then proceeds to argue that comparison is like metaphor. Donald Davidson argues that metaphors are not bearers of a hidden meaning, but are pragmatic devices that invite us to notice aspects of reality that we did not notice before. Metaphor stimulates thought and imagination to attend to previously unnoticed resemblances between things (98).

If this is true, then metaphorical comparison would prove a powerful method for theology. Nicholson argues that comparative theology utilizes that method. However, this is not the genealogical comparison of previous comparative theologies, which looked for religious sameness through historical relations. Instead, this is an analogical comparison which seeks intellectual stimulation through placing the familiar into novel, illuminating contexts, as does metaphor (200). In the end, the practice of comparison frees theological reflection from being habitual and automatic, thereby freeing its practitioners from determination by inherited tradition.

Such a penetrating analysis would be compromised were it not applied. To apply his theory, in Part II Nicholson compares Eckhart with Sankara, partly to deconstruct the 
East/West dichotomy that still persists in religious studies, and partly to rehabilitate Otto, who had succumbed to that very dichotomy. Alas, restrictions of space prevent addressing this section.

Of course, a book as novel and stimulating as Nicholson's will leave many readers' questions unanswered. Here, I would like to pose one question for clarification.

My question regards Nicholson's assertion that the first moment of relational identity formation, the exclusive moment, is inevitable and therefore not a fruitful area for theological discussion. I agree that all theological positions are exclusive-non-comparativists do not present at the Comparative Theology group of the AAR. Yet I also believe that the form of exclusion liberals advocate must be supported by argument over against the form of exclusion that fundamentalists advocate. Comparativists and fundamentalists exclude each other, this is true. But then to simply label both as exclusivists and move on disregards the extraordinary ethical and practical implications of their varying positions. These implications must be addressed, and if addressing them contributes to the identity formation of the comparative community, then so be it. My concern is that Nicholson has neglected the first moment of identity formation and skipped too readily to the second. In order to mature as a discipline, I believe that comparative theology must reflect rigorously on both moments.

This question is relatively minor given the enormous research and perceptive analysis that Nicholson presents. His book is a pioneering contribution to the nascent field of fundamental comparative theology. In the years to come, it will help comparative theology to proceed with greater awareness, confidence, and charity.

Jon Paul Sydnor

Emmanuel College

\section{The Rhythm of Being: The Gifford Lectures by Raimon Panikkar. Maryknoll, N.Y.: Orbis, 2010, 550 pp.}

THIS book consists of an edited version of the Gifford Lectures of 1989 which Panikkar continued to elaborate in the years following. It brings forth additional work incorporating material from Christophany: The Fullness of Man (2004) and the Experience of God: Icons of Mystery (2006). This book is his final testament. A great strength of the book is an inclusion of footnotes from Latin, Greek, German, French, Italian and Castilian in addition to Sanskrit. Much of Panikkar's thought revolves around the meaning of metaphysical terms in various linguistic registers," homeomorphic equivalents," as he calls them. His search for concepts ranges widely over Plato, Aristotle, Aquinas, Plotinus, Heraclitus, Kant, Hegel, and Heidegger as well as Shankara, Ramanuja, Abinavagupta, and others, not to mention
Catholic theologians who are alluded to occasionally such as Rahner, Marechal, Maritain, and an assortment of Christian mystics.

In many instances, Panikkar makes passing reference to the history of western philosophy which reflects an impressive grasp of many deep and long standing questions such as the meaning of esse, of time, of becoming, of cosmos, of motion, of matter, of consciousness, not only in a Western key but also in an Eastern key,with constant reference to the Upanishads.

These lectures do not engage traditional problems such as the way that Christology ties to Trinity, as in the classic problem of the hypostatic union, since Panikkar 's focus is on the cosmic Christ as a principle. His Trinitarian focus is not so much on the immanent Trinity as on the cosmotheandric 